\title{
Traumatic ulcerative granuloma with stromal eosinophilia (TUGSE): a rare self-healing oral mucosal lesion
}

\author{
Abhishek Banerjee, ${ }_{1}^{1}$ Satya Ranjan Misra, ${ }^{2}$ Vivek Kumar, ${ }_{1}^{1}$ Neeta Mohanty ${ }^{3}$
}

${ }^{1}$ Oral \& Maxillofacial Pathology, Awadh Dental College and Hospital, Jamshedpur, Jharkhand, India

${ }^{2}$ Oral Medicine \& Maxillofacial Radiology, Institute of Dental Sciences, Siksha 'O' Anusandhan Deemed to be University, Bhubaneswar, India

${ }^{3}$ Oral \& Maxillofacial Pathology \& Microbiology, Institute of Dental Sciences, Siksha 0 Anusandhan Deemed to be University, Bhubaneswar, Odisha, India

\section{Correspondence to}

Professor Neeta Mohanty; neetamohanty@soa.ac.in

Accepted 6 August 2021

Check for updates

(C) BMJ Publishing Group Limited 2021. No commercial re-use. See rights and permissions. Published by BMJ.

To cite: Banerjee $A$,

Misra SR, Kumar V, et al. BMJ

Case Rep 2021:14:e245097.

doi:10.1136/bcr-2021

245097

\section{DESCRIPTION}

Oral ulceration is a common report encountered by the oral physician, and a solitary ulcer of long duration especially when it is asymptomatic and occurs in middle aged and elderly patients is always under suspicion for oral squamous cell carcinoma. ${ }^{1}$ Chronic trauma of the oral mucosa (CTOM) due to repeated mechanical irritation from an intraoral injury agent has been debated as an oral potentially malignant disorder contributing to oral carcinogenesis and needs to be evaluated ruling out other associated contributing factors like tissue abuse habits and oral hygiene. ${ }^{2}$ Traumatic ulcerative granuloma with stromal eosinophilia (TUGSE) is an uncommon self-limiting oral mucosal lesion. It presents as a single ulcer which may be asymptomatic or associated with pain with the dorsum or the tip of the tongue being the most common site. The importance of this rare lesion lies in the fact that it is often misdiagnosed as oral carcinoma or specific infections like tuberculosis, primary syphilis or Epstein-Barr virus ulcer. Biopsy is mandatory and exhibits typical histological findings diffuse polymorphic inflammatory infiltrate, predominately consisting of histiocytes, activated and predominantly T-lymphocytes, and of eosinophils with the lesion extending deep into the submucosa, deeper muscle fibres and even the salivary glands. ${ }^{3}$ Eosinophils are known to regulate local inflammatory and immune responses; hence, their presence is associated with inflammation and infection and their abundance in this lesion indicates an associated inflammatory component. The aetiopathogenesis of TUGSE is debatable but a localised traumatic cause is a significant predisposing factor as seen in this case, though it may be absent in half of the cases. ${ }^{4}$ These lesions show a male gender predilection with an age range of 41-60 years. The lesions generally heal following biopsy. TUGSE is entirely a histologic entity and is incidentally diagnosed when lesions associated with CTOM are biopsied suspecting malignancy.

A 35-year-old woman presented with an ulcer in the right buccal mucosa which had been present for about 7 months. History revealed the ulcer had been associated with pain and did not increase in size over time. The patients' medical history was unremarkable. On clinical examination, a single irregular ulcer measuring $1 \mathrm{~cm} \times 1.5 \mathrm{~cm}$ in size was seen on the right buccal mucosa in relation to carious maxillary molars 17,16 . The floor of the ulcer was erythematous and the borders irregular

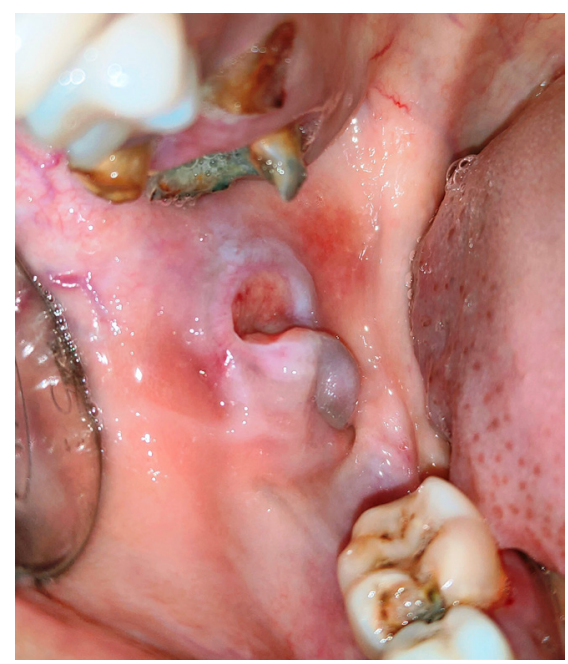

Figure 1 A solitary, irregular ulcer on the right buccal mucosa in relation to carious maxillary molars having an erythematous floor and irregular hyperkeratotic white borders with indentation of the tooth cusp of maxillary molar on the ulcer surface.

and whitish in colour. The indentation of the tooth cusp of maxillary molar was apparent on the ulcer surface (figure 1). On palpation, the base appeared

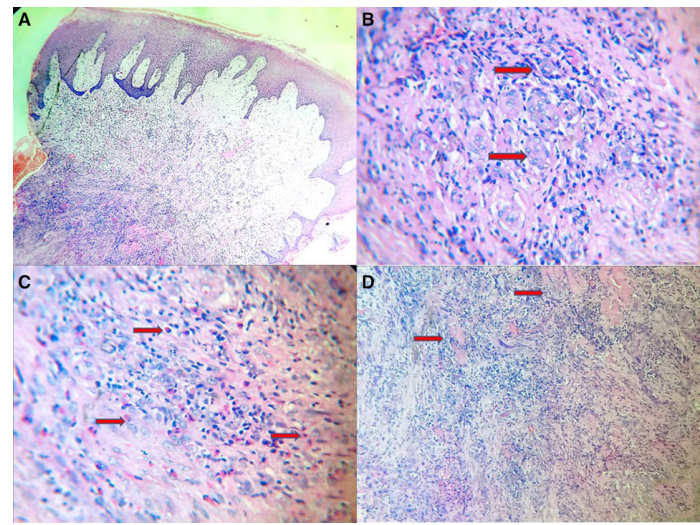

Figure 2 H\&E-stained section showing (A) infiltrative lesion with dense granulomatous reaction in the stroma (original magnification $5 x$ ) and (B) infiltration of the chronic inflammation at the level of deeper connective tissue extending into the musculature (original magnification 10x). At higher magnification, presence of (C) tissue macrophages along with budding vascular channels and lymphocytes and (D) pool of eosinophils along with other components of chronic inflammation are seen (original magnification 40x). 


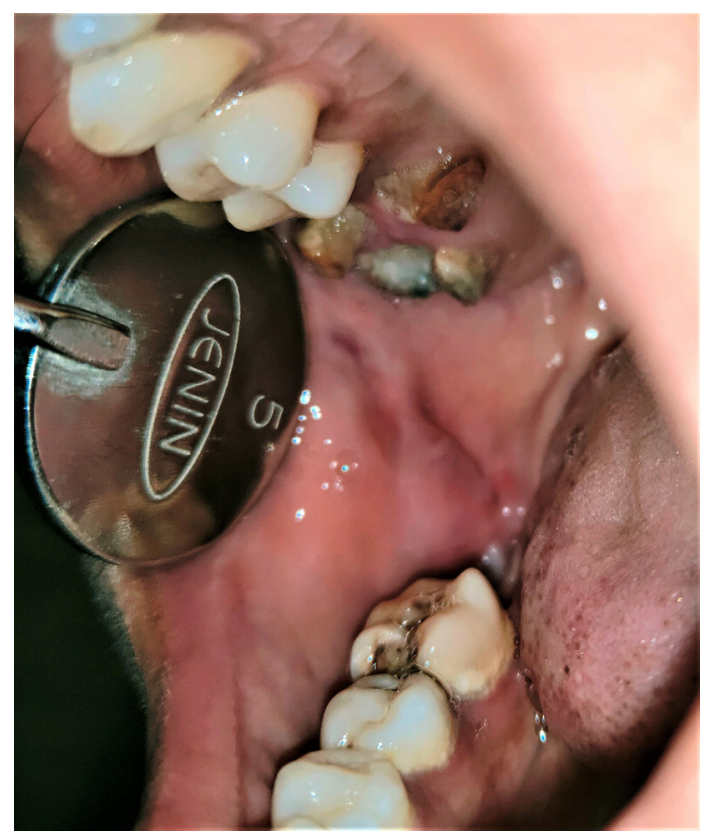

Figure 3 Healed ulcer on the right buccal mucosa indicating the selflimiting nature of the lesion.

indurated and was slightly tender. As it was a long-standing solitary ulcer, chronic traumatic ulcer, tuberculous ulcer and malignant ulcer were considered in the clinical differential diagnosis.

Routine haematologic investigations and panoramic radiography were unremarkable. As the patient was unwilling for tooth extraction, the sharp edges of the maxillary molars on the right side were smoothened to relieve the pain. An excisional biopsy was performed under local anaesthesia and the tissue was sent for histopathological evaluation owing to the duration of this longstanding non-healing lesion. The H\&E-stained sections revealed that the lesion was infiltrative and involving the striated muscle with a para-keratinised hyperplastic epithelium (figure 2A,B).

\section{Learning points}

- Traumatic ulcerative granuloma with stromal eosinophilia (TUGSE) is a rare ulcerative oral mucosal lesion.

- TUGSE often mimics infectious diseases or malignancy, thereby making biopsy mandatory for diagnosis along with a meticulous clinical examination.

- It does not mandate any specific treatment except topical analgesic-anaesthetic gel may be applied for symptomatic relief.

The stroma was abundantly infiltrated with chronic inflammatory infiltrate-like lymphocytes, histiocytes and pool of eosinophils at focal areas (figure 2C,D). A granulomatous pattern seen in the stroma with focal areas of degeneration without any cell atypia. The histopathologic features indicated TUGSE and the patient was kept on regular follow-up and the lesion almost completely healed in 3 months (figure 3 ).

Contributors SRM examined the patient and performed the biopsy. AB and VK performed the histopathologic evaluation. NM prepared the manuscript.

Funding The authors have not declared a specific grant for this research from any funding agency in the public, commercial or not-for-profit sectors.

Competing interests None declared.

Patient consent for publication Obtained.

Provenance and peer review Not commissioned; externally peer reviewed.

\section{REFERENCES}

1 Segura S, Pujol RM. Eosinophilic ulcer of the oral mucosa: a distinct entity or a nonspecific reactive pattern? Oral Dis 2008;14:287-95.

2 Piemonte ED, Lazos JP, Brunotto M. Relationship between chronic trauma of the oral mucosa, oral potentially malignant disorders and oral cancer. J Oral Pathol Med 2010;39:no-7.

3 Chandra S, Raju S, Sah K, et al. Traumatic ulcerative granuloma with stromal eosinophilia. Arch Iran Med 2014;17:91-4.

4 Hirshberg A, Amariglio N, Akrish S, et al. Traumatic ulcerative granuloma with stromal eosinophilia: a reactive lesion of the oral mucosa. Am J Clin Pathol 2006;126:522-9.

Copyright 2021 BMJ Publishing Group. All rights reserved. For permission to reuse any of this content visit

https://www.bmj.com/company/products-services/rights-and-licensing/permissions/

BMJ Case Report Fellows may re-use this article for personal use and teaching without any further permission.

Become a Fellow of BMJ Case Reports today and you can:

- Submit as many cases as you like

- Enjoy fast sympathetic peer review and rapid publication of accepted articles

- Access all the published articles

- Re-use any of the published material for personal use and teaching without further permission

\section{Customer Service}

If you have any further queries about your subscription, please contact our customer services team on +44 (0) 2071111105 or via email at support@bmj.com.

Visit casereports.bmj.com for more articles like this and to become a Fellow 